\title{
Inhaled magnesium sulfate in the treatment of acute asthma in children
}

Rebecca Normansell ${ }^{1}$, Rachel Knightly ${ }^{2}$, Stephen J Milan ${ }^{3}$, Jennifer A Knopp-Sihota ${ }^{4}$, Brian H Rowe ${ }^{5,6}$, Colin Powell ${ }^{7}$

1. Cochrane Airways, Population Health Research Institute, St George's, University of London, London, UK

2. Population Health Research Institute, St George's, University of London, UK

3. Lancaster Health Hub, Lancaster University, Lancaster, UK

4. Faculty of Health Disciplines, Athabasca University, Edmonton, Canada

5. Department of Emergency Medicine, University of Alberta, Edmonton, Canada

6. School of Public Heath, University of Alberta, Edmonton, Canada

7. Department of Child Health, The Division of Population Medicine, The School of Medicine, Cardiff University, Cardiff, UK

\section{WHY WAS IT IMPORTANT TO DO THIS COCHRANE REVIEW ${ }^{1}$}

Asthma is a chronic respiratory disease characterised by reversible airflow obstruction, with periods of relative control and episodes of deterioration referred to as exacerbations. Exacerbations range in severity from mild to life-threatening and may require emergency department management and brief hospitalisations. Although rare, admissions to intensive care, mechanical ventilation and deaths from severe acute asthma exacerbations do still occur ${ }^{2}$.

In the UK, the condition affects one in 11 children; a child is admitted to hospital every 20 minutes due to asthma ${ }^{3}$. Options for treating exacerbations include inhaled bronchodilators such as salbutamol and ipratropium, systemic steroids and other supportive measures such as oxygen ${ }^{4}$. Magnesium sulfate has been proposed as a possible additive treatment in acute asthma, and has been shown to be effective in severe acute asthma when delivered intravenously ${ }^{5}$. However, there is more uncertainty about the role of inhaled or nebulised magnesium sulfate. British Thoracic Society/Scottish Intercollegiate Guidelines Network (BTS/SIGN) Asthma Guidelines do not recommend its use at all in adults and only if other treatments have failed in the context of a severe asthma exacerbation of short duration in children ${ }^{3}$.

A previous version of this review published in 2012 found insufficient evidence, particularly in children, to either clearly support or refute the use of inhaled magnesium sulfate. Several large trials have been published in recent years, including studies in children, necessitating an update of this review $^{1}$. The published review used established Cochrane methods and includes studies in all ages; data relating to children are presented here.

\section{WHAT WERE THE OBJECTIVES OF THE REVIEW?}

The aim of the review was to assess whether giving inhaled magnesium for acute asthma is (1) safe, (2) whether it improves lung function, (3) reduces the need for admission and (4) reduces asthma symptom/severity scores.

\section{WHAT WAS THE EVIDENCE BASE OF THE REVIEW?}


We included eight randomised controlled trials involving a total 1247 children in the review. Populations, interventions and procedures varied across the eight studies. We chose to extract outcomes at, or as close as possible to, 60 minutes post-baseline. We identified three main comparisons:

1. Nebulised salbutamol and ipratropium plus magnesium sulfate versus nebulised salbutamol and ipratropium alone (two studies)

2. Nebulised salbutamol plus magnesium sulfate versus nebulised salbutamol alone (five studies)

3. Nebulised magnesium sulfate alone versus nebulised salbutamol alone (one study).

Most of the studies, when specified, allowed co-interventions including systemic corticosteroids. Sample sizes ranged from 17 to $>500$ participants with the larger trials conducted more recently. Children ranged from two to 17 years of age and had predominantly moderate to severe acute asthma, variably defined, at the time of study enrolment (Table 1).

While we judged most trials to be at low risk of bias overall, there was uncertainty about selection bias in four trials and bias related to performance and detection in three trials. We considered two trials to be at high risk for reporting bias. Our confidence in the results is reduced by the limited number of meta-analyses we were able to perform, largely due to heterogeneity of the interventions and outcomes reported.

\section{WHAT WERE THE FINDINGS OF THE REVIEW?}

Percent predicted forced expiratory volume in one second (FEV1) was reported by one study, favouring the addition of magnesium to salbutamol, but the confidence interval $(\mathrm{Cl})$ suggests no statistical difference (mean difference $8.10,95 \% \mathrm{Cl}-3.03$ to $19.23 ; \mathrm{n}=62$ ). A further study investigating the same comparison reported peak expiratory flow (PEF) and while the addition of magnesium is again favoured, the result is uncertain (MD $11.90 \mathrm{~L} / \mathrm{min}, 95 \% \mathrm{Cl}-6.86$ to $30.66 ; \mathrm{n}=80$ ). No significant difference was found in three trials comparing magnesium to other non-magnesium treatments for admission to hospital (Risk ratio $0.97,95 \% \mathrm{Cl} 0.92$ to $1.02 ; n=670$ ). One study reported clinical severity using the Yung Asthma Severity Score (ASS) ${ }^{6}$. The result favoured the magnesium group at 60 minutes, but this is unlikely to reflect a clinically important difference, and again, the $\mathrm{Cl}$ includes zero ( $\mathrm{MD}-0.17,95 \% \mathrm{Cl}-0.35,0.02 ; \mathrm{n}=472$ ), indicating no statistical difference between groups. Serious adverse events were rare but slightly less frequent in the magnesium group (Risk difference $-0.031,95 \% \mathrm{Cl}-0.058$ to $-0.004 ; \mathrm{n}=569$ ).

Of note, the largest study in children reported subgroup analysis for their primary outcome, ASS, investigating whether participants with a more severe asthma exacerbation or an exacerbation of shorter duration derived more benefit from the addition of nebulised magnesium. Although not powered to detect a difference, the study results support this hypothesis ${ }^{7}$.

\section{WHAT ARE THE IMPLICATIONS OF THIS REVIEW FOR PRACTICE AND FOR RESEARCH?}

Treatment with nebulised magnesium sulfate is likely to be safe and may result in modest additional benefits for children when added to inhaled salbutamol and ipratropium bromide; however, our confidence in the evidence is low and there remains substantial uncertainty. Evidence from one large trial suggests children with a more severe exacerbation or shorter duration of symptoms may experience a greater benefit; this is reflected in current guidance (BTS/SIGN) ${ }^{3,7}$. Due to heterogeneity of outcome measures we were able to perform very limited meta-analyses and unable to implement our planned subgroup analysis for severity. There is little evidence regarding the use of nebulised 
magnesium sulfate as an alternative to salbutamol and it is unlikely that future trials will address this question directly.

Further placebo-controlled trials in participants with severe asthma exacerbations or with symptoms of short duration not responding to standard maximal treatment may help establish if nebulised magnesium sulfate has a role in this context. However, the accumulating evidence suggests that a substantial benefit may be unlikely. Trials comparing the safety and efficacy of nebulised magnesium to intravenous magnesium are also of interest.

TABLE 1

\begin{tabular}{|l|l|l|l|l|l|l|}
\hline ID & Country & $\begin{array}{l}\text { Total } \\
\mathbf{n}\end{array}$ & $\begin{array}{l}\text { Age range } \\
\text { (years) }\end{array}$ & Inclusion & $\begin{array}{l}\text { Magnesium } \\
\text { regimen }\end{array}$ & Co-treatments \\
\hline $\begin{array}{l}\text { Turker } \\
2017^{8}\end{array}$ & Turkey & 100 & 3 to 15 & $\begin{array}{l}\text { Moderate } \\
\text { asthma } \\
\text { exacerbation }\end{array}$ & $\begin{array}{l}\text { Three doses at } \\
\text { 20 minutes } \\
\text { intervals }\end{array}$ & $\begin{array}{l}\text { Salbutamol, } \\
\text { prednisolone }\end{array}$ \\
\hline $\begin{array}{l}\text { Alansari } \\
2015^{9}\end{array}$ & Qatar & 400 & 2 to 14 & $\begin{array}{l}\text { Moderate to } \\
\text { severe asthma } \\
\text { exacerbation }\end{array}$ & $\begin{array}{l}\text { Three doses } \\
20 \text { minutes } \\
\text { intervals }\end{array}$ & $\begin{array}{l}\text { Salbutamol, } \\
\text { ipratropium, } \\
\text { prednisolone }\end{array}$ \\
\hline $\begin{array}{l}\text { Mohamm } \\
\text { edzadeh } \\
2014^{10}\end{array}$ & Iran & 80 & 5 to 14 & $\begin{array}{l}\text { Moderate to } \\
\text { severe asthma } \\
\text { exacerbation }\end{array}$ & $\begin{array}{l}\text { Three doses at } \\
20 \text { minutes } \\
\text { intervals }\end{array}$ & Not stated \\
\hline $\begin{array}{l}\text { Powell } \\
2013^{7}\end{array}$ & UK & 508 & 2 to 16 & $\begin{array}{l}\text { Severe asthma } \\
\text { exacerbation } \\
\text { after } \\
\text { conventional } \\
\text { treatment }\end{array}$ & $\begin{array}{l}\text { Three doses at } \\
20 \text { minutes } \\
\text { intervals }\end{array}$ & $\begin{array}{l}\text { Hospital- } \\
\text { defined } \\
\text { standard } \\
\text { treatment }\end{array}$ \\
\hline $\begin{array}{l}\text { Ashtekar } \\
2008^{11}\end{array}$ & UK & 17 & 2 to 16 & $\begin{array}{l}\text { Severe asthma } \\
\text { exacerbation }\end{array}$ & $\begin{array}{l}\text { Three doses at } \\
20 \text { minutes } \\
\text { intervals }\end{array}$ & $\begin{array}{l}\text { Ipratropium, } \\
\text { salbutamol, } \\
\text { prednisolone }\end{array}$ \\
\hline $\begin{array}{l}\text { Khashabi } \\
2008^{12}\end{array}$ & Iran & 40 & Mean 3.55 & $\begin{array}{l}\text { "Asthmatic } \\
\text { children" }\end{array}$ & $\begin{array}{l}\text { Two doses of } \\
\text { (interval } \\
\text { unclear) }\end{array}$ & $\begin{array}{l}\text { Salbutamol; } \\
\text { other co- } \\
\text { treatments not } \\
\text { stated }\end{array}$ \\
\hline $\begin{array}{l}\text { Mahajan } \\
2004^{13}\end{array}$ & USA & 62 & 5 to 17 & $\begin{array}{l}\text { Acute asthma } \\
\text { exacerbation, } \\
\text { FEV1 between } \\
45 \% \text { and 75\% } \\
\text { predicted }\end{array}$ & $\begin{array}{l}\text { PEF decreased } \\
\text { by } \geq 25 \% .\end{array}$ & $\begin{array}{l}\text { One dose } \\
\text { palbutamol, } \\
\text { prednisolone }\end{array}$ \\
\hline Turkey & 40 & "Paediatric" & $\begin{array}{l}\text { Onese } \\
\text { (control group } \\
\text { only) }\end{array}$ \\
\hline
\end{tabular}

\section{REFERENCES}

1. Knightly R, Milan SJ, Hughes R, Knopp-Sihota JA, Rowe BH, Normansell R, Powell C Inhaled magnesium sulfate in the treatment of acute asthma. Cochrane Database of Systematic Reviews (in press)

2. Royal College of Physicians. Why asthma still kills: the national review of asthma deaths (NRAD) confidential enquiry report. rcplondon.ac.uk/projects/outputs/why-asthma-still-kills. [ISBN 978-1-86016-531-3] 
3. Asthma UK. Facts and statistics. https://www.asthma.org.uk/about/media/facts-andstatistics/

4. British Thoracic Society and Scottish Intercollegiate Guidelines Network. British guideline on the management of asthma. A national clinical guideline. 2016. https://www.brit-

thoracic.org.uk/guidelines-and-quality-standards/asthma-guideline/

5. Griffiths B, Kew KM. Intravenous magnesium sulfate for treating children with acute asthma in the emergency department. Cochrane Database of Systematic Reviews 2016;(Issue 4). http://dx.doi.org/10.1002/14651858.CD011050.pub2. Art. No.: CD011050.

6. Yung M, South M, Byrt T. Evaluation of an asthma severity score. J Paediatr Child Health. 1996;32(3):261-4.

7. Powell C, Kolamunnage-Dona R, Lowe J, Boland A, Petrou S, Doull I, et al. Magnesium sulphate in acute severe asthma in children (MAGNETIC): a randomised, placebo-controlled trial. Lancet Respiratory Medicine 2013;1(4):301-8

8. Turker S, Dogru M, Yildiz F, Yilmaz SB. The effect of nebulised magnesium sulphate in the management of childhood moderate asthma exacerbations as adjuvant treatment. Allergologia et immunopathologia 2017;45(2):115-20

9. Alansari K, Ahmed W, Davidson B, Alamri M, Zakaria I, Alrifaai M. Nebulized magnesium for moderate and severe pediatric asthma: a randomized trial. Pediatric Pulmonology 2015;50(12):1191-9

10. Mohammedzadeh I, Mohammadi M, Khodabakhsh E. Effect of salbutamol and magnesium sulfate nebulizer compared with salbutamol and normal saline nebulizer in the treatment of acute asthma attack. Journal of Babol University of Medical Sciences 2014;16(3):7-12.

11. Ashtekar CS, Powell C, Hood K, Doull I. Magnesium nebuliser trial (magnet): a randomised double-blind placebo controlled pilot study in severe acute asthma. Archives of Disease in Childhood 2008;93:A100-6. [CRSREF: 3326068]

12. Khashabi J, Asadolahi S, Karamiyar M, Salari Lak S. Comparison of magnesium sulfate to normal saline as a vehicle for nebulized salbutamol in children with acute asthma: a clinical trial [Abstract]. In: European Respiratory Society 18th Annual Congress; 2008 Oct 3-7; Berlin. 2008:[4597]. [CRSREF: 3326085]

13. Mahajan P, Haritos D, Rosenberg N, Thomas R. Comparison of nebulized magnesium plus albuterol to nebulized albuterol plus saline in children with mild to moderate asthma. Journal of Emergency Medicine 2004;27(1):21-5. [CRSREF: 3326090]

14. Meral A, Coker M, Tanac R. Inhalation therapy with magnesium sulfate and salbutamol in bronchial asthma. Turkish Journal of Pediatrics 1996;38(2):169-75. [CRSREF: 3326094] 